DOI: 10.34015/2523-4552.2021.3.10

УДК 340.15

Шуліка В. I.,

аспірант кафедри теорії та

історії держави і права

Волинського національного

університету імені Лесі Українки

ORCID: 0000-0003-3202-0463

\title{
ІСТОРІОГРАФІЯ ПЕНІТЕНЦІАРІЇ ВЕЛИКОБРИТАНІЇ В УКРАЇНСЬКІЙ ПРАВОВІЙ ДУМЦІ
}

У статті розглянуто історіографію пенітенціарного права Великобританії у вітчизняній правовій думці, здійснено аналіз доробку українських дослідників пенітенціарної системи Великобританії. Проаналізовано наукові роботи в галузі кримінального та кримінально-виконавчого права Великобританії та їх роль у вдосконаленні пенітенціарної системи України. 3'ясовано основні проблемні аспекти функціонування пенітенціарної системи та синтезовано перспективи подальших досліджень системи виконання покарань Великобританії для окреслення можливих шляхів реформування пенітенціарної системи України.

Ключові слова: пенітенціарне право; пенітенціарне право Великобританії; пенітенціарія; пенітенціарна система; історіографія пенітенціарії.

В статье рассмотрена историография пенитенциарного права Великобритании в отечественном правовом мнении, проведен анализ наследия украинских исследователей пенитенциарной системы Великобритании. Проанализированы научные работы в области уголовного и уголовноисполнительного права Великобритании и их роль в усовершенствовании пенитенциарной системы Украины. Выяснены основные проблемные аспекты функционирования пенитенциарной системы и синтезированы перспективы дальнейших исследований системы исполнения наказаний Великобритании для определения возможных путей реформирования пенитенциарной системы Украины.

Ключевые слова: пенитенциарное право; пенитенциарное право Великобритании; пенитенциария; пенитенциарная система; историография пенитенциарии.

Постановка проблеми. Проблематика досліджуваної теми зумовлена відсутністю комплексного дослідження пенітенціарної системи Великої Британії в українській правовій думці. Крім того, сьогодні триває реформування пенітенціарної системи України, мета якої $є$ ство- рення гуманістичної системи виконання кримінальних покарань, що гарантуватиме безпеку суспільства та забезпечуватиме соціальне зцілення людини. Проблемними аспектами української пенітенціарії і до сьогодні залишаються недостатньо ефективні інструменти моти- 
вації засуджених до праці та освіти, корекційно-реабілітаційних та інших програм, а також відсутність кваліфікованих фахівців для ефективного впровадження таких програм, відсутність механізму реінтеграції засуджених в суспільство після звільнення, який допомагав би зменшувати ризик вчинення нових злочинів завдяки побутовому влаштуванню (суспільно-корисні зв'язки, житло, робота, лікування залежності тощо), умови тримання, медичне та матеріально-технічне забезпечення засуджених та ув'язнених не відповідають сучасним вимогам та Європейським пенітенціарним правилам, що не сприяє виправленню засуджених. Саме для усунення вказаних проблем функціонування української пенітенціарної системи необхідним $\epsilon$ вивчення та запозичення позитивного досвіду функціонування пенітенціарної системи Великобританії.

Аналіз останніх досліджень і публікацій. Теоретико-прикладні розробки виконання та відбування покарань й окремі порівняльноправові дослідження в різні історичні періоди вітчизняної й зарубіжної юриспруденції здійснювали: Л. В. Багрій-Шахматов, Ю. В. Баулін, В. І. Борисов, І. Г. Богатирьов, М. М. Гернет, С. Ф. Денисов, О. М. Джу$\begin{array}{lll}\text { жа, } & \text { О. А. Долгий, } & \text { В. М. Дрьомін, }\end{array}$ O. І. Зубков, О. Ф. Кістяківський, В.В.Коваленко, О. Г. Колб, Н. В. Коломієць, I. М. Копотун, О.М.Литвинов, В. Г. Лихолоб, О. О. Малиновський, В. О. Меркулова, П. П. Михайленко, С. С. Мірошниченко, В. М. Пальченкова, С. В. Познишев, Г. О.Радов, О. П. Рябчинська, А. В. Савченко, М. Д. Сергеєвський, $\quad$ С. С. Яценко, М. М. Яцишин та ін.
Безпосередньо дослідження питань виконання та відбування покарань у зарубіжних країнах проводила низка науковців радянського та сучасного періодів (Р. О. Андреященко, 3. А. Астеміров, О. І. Бажанов, К. Ж. Балтабаєв, Є. П. Бурдо, А. М. Бурцев, І. Б. Вікторова, М. Л. Греков,

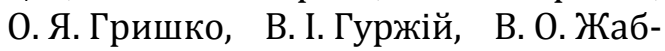
ський, В. О. Зайченко, Ю. В. Калінін, О. О. Ложніков, О.Ф. Маруков, М. П. Мєлєнтьєв, Н. І. Наришкіна, М. О. Стручков, П. В. Тепляшин, Н. Б. Хуторська, Ю. В. Чакубаш, В. П. Шупілов та ін.), а також відомі західноєвропейські й американські вченіправники (Т. Агелвік, М. Босворт, Х. Вааль, К. Гофф, Дж. Даллам, Г. Деммер, Дж. Дігнен, Ш. Доловіч, Ф. Дюнкел, М. Кавадіно, Е. Койл, Н. Крісті, та ін.). Однак недостатньо уваги, на нашу думку, приділялося досвіду провадження державної політики у сфері виконання кримінальних покарань у Великобританії. 3 огляду на це, пропонуємо окреслити найбільш цікаві, на нашу думку, дослідження пенітенціарної системи Великої Британії в українській правовій думці.

\section{Постановка}

завдання.

Здійснити аналіз історіографії пенітенціарії Великої Британії в українській правовій думці, з метою виявлення можливих шляхів реформування пенітенціарної системи України шляхом запозичення позитивного досвіду Великобританії; окреслити перспективи подальших досліджень пенітенціарної системи Великобританії.

Виклад основного матеріалу. Аналіз історіографії пенітенціарної системи Великобританії варто розпочати 3 наукових розробок представника Одеської школи кри- 
мінального та кримінальновиконавчого права М. І. Хавронюка, котрий у своїх працях справедливо зазначає про взаємозв'язок елементів національної кримінальноправової системи не лише між собою, а й 3 відповідними елементами зарубіжних кримінально-правових систем. Зокрема вчений акцентує увагу на тому, що українська доктрина кримінального права існує і розвивається з урахуванням відомих нам досягнень зарубіжної доктрини кримінального права, правильних та помилкових рішень кримінальноправової політики і положень кримінального законодавства інших держав. Автор аргументовано зазначає, що новели в українському кримінальному законодавстві з'являються часто під впливом апробованих на практиці положень законодавства інших держав або результатів наукових досліджень зарубіжних учених. У результаті чого, кримінально-правові норми в Україні застосовуються з урахуванням певною мірою того, як аналогічні норми застосовуються в інших державах. До того ж, М. І. Хавронюк нагадує про те, що вчені-криміналісти різних країн на міжнародних конференціях діляться між собою досвідом викладання кримінального права як навчальної дисципліни, а населення різних країн, буваючи за кордоном особисто або отримуючи із ЗМІ новини 3-за кордону, не лише дивується кримінально-правовій культурі населення інших країн, а часто і переймає ïi найкращі зразки та підштовхує національних законодавців до зміни тих чи інших законів про кримінальну відповідальність. Усі перелічені вище аспекти впливу доктринально- го та міжгалузевого дослідження пенітенціарії слугують підтвердженням актуальності дослідження пенітенціарії Великобританії [1, c. 299].

Вдаючись до змістовного аналізу історіографії пенітенціарної системи Великобританії, цікаво зазначити, що у своєму дослідженні М. М. Яцишин та Ю.П.Крисюк вказують на основний принцип функціонування англійської пенітенціарії, формуванню якого із початку реформ в середині 1960-х років сприяв усталений у соціології консенсус, відомий як «nothing works» doctrine. Згідно 3 цією доктриною, ефективність будь-яких програм реабілітації злочинців 3 точки зору профілактики рецидивізму надзвичайно низька [2]. Однак у різних країнах із цієї доктрини зробили різні висновки. США та, значною мірою, Великобританія пішли шляхом нарощування рівня інкарцерації за принципом «Якщо злочинця не можна виправити, то його хоча б можна знешкодити, ізолювавши від суспільства» [3]. Вважаємо за доцільне погодитись із такою думкою науковців, оскільки, очевидно, що система норм, передбачених кримінально-виконавчим кодексом України побудована таким чином, щоб особу, яка являє собою суспільну небезпеку для оточуючих принаймні можна ізолювати від суспільства, а, в перспективі, виправити. Висновок про виправлення може бути зроблений уповноваженим органом 3 питань пробації шляхом надсилання до суду подання про умовно-дострокове звільнення засудженого від покарання, 3 урахуванням характеристики засудженого, підготовленої власником 
підприємства, установи, організації або уповноваженим ним органом за місцем роботи засудженого.

Цікавим вважаємо те, що в Англії (Великобританії), тюремна система якої по праву вважається не тільки найстарішою в Європі, але й, завдяки постійному реформуванню, досить досконалою. Сьогодні пенітенціарна система Великобританії включає місцеві (відбувають покарання засуджені тієї місцевості, де вони проживали до арешту та засуджені на незначний строк) та центральні тюрми. Діяльність пенітенціарних установ Великобританії регламентується сукупністю прецедентів, норм кримінального, кримінально-процесуального і пенітенціарного права, спеціальним законом «Про тюрми» від 1952 р. та законами «Про кримінальне право» від 1967 р., «Про кримінальне право» від 1977 р., «Про поліцію і докази з кримінальних справ» від 1984 р., «Про кримінальну юстицію» від 1988 р., «Про кримінальну юстицію» від 1991 р., «Про кримінальну юстицію» 1993 р. у тюрмах Великобританії підтримується суворий порядок та жорсткі заходи безпеки [4].

Крім того, серед вітчизняних дослідників пенітенціарії Великої Британії слід згадати М. С. Пузирьова, котрий у своїй праці “Виконання покарання у виді позбавлення волі на певний строк у зарубіжних країнах: порівняльно-правове дослідження" окреслює загальні особливості пенітенціарії Великобританії. Наприклад, науковець вказує, що в Англії та Уельсі відсутня кодифікація норм кримінального та кримінально-виконавчого права. Відсутність кодифікації у кримінально-правовій та кримінально- виконавчій галузях, віднесення до джерел права судового прецеденту розширює можливості суду під час індивідуалізації призначення покарання. Цей фактор впливає і на реалізацію принципів диференціації та індивідуалізації під час виконання покарань. Виконання покарання у виді позбавлення волі на певний строк в Англії та Уельсі регламентується законами «Про кримінальну юстицію» 2003 р., «Про тюрми» 1952 р., Тюремними правилами 1999 р., Правилами функціонування установ для молодих злочинців 2000 р., іншими нормативноправовими актами Міністерства юстиції Великої Британії. Крім того, у дисертаційному дослідженні автор зазначає, що управління кримінально-виконавчою системою Англії та Уельсу здійснює Служба тюрем і пробації, яка $\epsilon$ виконавчим органом Міністерства юстиції. Незважаючи на те, що приватний сектор здійснює управління $11 \%$ тюрем, перевезення засуджених та ув'язнених, а також охорона й підтримання порядку в судах Англії та Уельсу здійснюються приватними компаніями. Водночас державні виправні установи, порівняно з тими, якими керують приватні компанії, характеризуються більш високим порядком і станом безпеки засуджених та персоналу. Це пояснюється значною економією коштів (до $20 \%$ ) приватними компаніями. М. С. Пузирьов у своїх працях з'ясував, що в тюрмах Англії та Уельсу найважливішим критерієм поділу (категоризації) засуджених $\epsilon$ ступінь загрози їхньої втечі, що зумовлює відповідну класифікацію установ виконання покарань, пов'язаних із позбавленням волі. Зокрема, установи виконання пока- 
рань, пов'язаних із позбавленням волі, в Англії та Уельсі за рівнем безпеки класифікуються таким чином: тюрми категорії «А» (максимальний рівень безпеки), категорії «В» (середній рівень безпеки), категорії «С» (напіввідкритого типу), категорії «D» (відкритого типу). При цьому передбачено можливість створення ізольованих відділень (секторів) вищого рівня безпеки в установах нижчого рівня. Цікаво, що у своїх дослідженнях М. С. Пузирьов доходить до висновку про більшу, порівняно 3 Англією та Уельсом, досконалість кримінально-виконавчого законодавства України, яка полягає в тому, що: 1) права, обов'язки та законні інтереси (пільги, заохочувальні норми) засуджених закріплено у кримінально-виконавчому кодексі України (далі - КВК України). Виходячи з цього, підзаконні нормативноправові акти (зокрема Правила внутрішнього розпорядку установ виконання покарань) не можуть розширювати перелік правообмежень засуджених; 2) КВК України в частині регулювання законних інтересів (пільг, заохочувальних норм) засуджених містить як матеріальні, так і процесуальні норми [5].

Тут зазначимо, що на правовому рівні система виконання покарань Великобританії відображена у Законі про в'язниці 1952 року. Втім, як справедливо зазначає дослідник пенітенціарного права Великобританії ще з часів Радянського Союзу Р.А. Андреященко, положення даного закону хоча й описують систему органів пенітенціарної системи, які здійснюють керівні, законотворчі та контрольні функції, втім не можна сказати про те, що вини роблять це повною мірою, оскільки в законі немає норм, що регулюють конкретні правовідносини всередині системи і встановлюють той або інший режим [6, с. 23].

До дослідження організаційноуправлінської структури пенітенціарної системи вдається К. В. Муравйов. Відтак, вчений звертає увагу на особливості ієрархії вказаної системи, яка знаходять свій прояв у тому, що очолює організаційноуправлінську структуру тюремної служби Великобританії генеральний директор (далі - Директор), який призначається Міністром внутрішніх справ 3 обов'язкового схвалення прем'єр-міністра. Учений окреслює і обов'язки Директора серед яких: безпосереднє управління роботою Тюремної служби щодо досягненню цілей і завдань, визначених у корпоративних планах і схвалених Міністром внутрішніх справ. Додатково до основних обов'язків Директор повинен займатися роботою громадських організацій, залучених у діяльність Тюремної служби. Окрім внутрішнього відомчого контролю, що здійснюється органами Тюремної служби у порядку підпорядкування, спостереження за законністю та ефективністю роботи служби здійснюють: королівські інспектори, тюремний омбудсмен, представники громадськості [7].

У свою чергу, у дослідженнях системи виконання покарань в Англії С. С. Яценко зазначає про такі її особливості: по-перше, в цілому, в Англії, різні уявлення про поняття кримінального покарання та його призначення (цілі) накладають суттєвий відбиток на практику його застосування. По-друге, головним видом покарання в Англії залишається позбавлення волі. За 
англійськими законами, це тюремне ув'язнення, максимальний строк якого становить 25 років. По-третє, практикою вироблено систему певних стандартів призначення покарання в вигляді позбавлення волі за різні злочини (систему тарифів) [8]. Крім того, до відомих праць С.С.Яценко слід віднести дисертаційне дослідження вченого "Уголовно-правовая охрана общественного порядка. (Сравнительно-правовое исследование)”, (Київ, 1988), а також навчальний посібник "Основні питання загальної частини кримінального права іноземних держав" (2013).

Висновки. В результаті окресленого нами матеріалу дослідження можемо резюмувати, що аналіз історіографії пенітенціарії Великобританії в українській правовій думці $\epsilon$ надзвичайно важливим та актуальним сьогодні з огляду на очевидний, як було нами доведено у статті, взаємний зв'язок елементів кримінально-правової системи України не лише між собою, а й із відповідними елементами зарубіжних кримінально-правових систем. Однак, на сьогодні недостатніми $\epsilon$ вже існуючі дослідження пенітенціарії Великобританії для повного окреслення ефективності її функціонування. Тому нагально i важливо $\epsilon$ продовжувати досліджувати особливості пенітенціарії зарубіжних країн з метою імплементації позитивного досвіду для ефективного та своєчасного вдосконалення вітчизняної пенітенціарної системи. Очевидно, що створення ефективної системи покарань є актуальною проблемою для всіх країн світу, а для Великобританії та України зокрема.

\section{Список використаних джерел}

1. Хавронюк М. І. Наукове осмислення правової доктрина та кримінального законодавства зарубіжних країн. Вісник Асоціації кримінального права України, 2013. No 1(1). С. 298-347.

2. National Criminal Justice Reference Service. URL: https://www.ncjrs.gov/App/ Publications/abstract.aspx?ID=74558

3. Яцишин М. М., Крисюк Ю. П. Перспективи реформування пенітенціарної системи України: досвід Фінляндії. Вісник пенітенціарної асоціації України. 2018. № 3(5). С. 102-110.

4. Тюремная система Великобритании. URL: http://tyurma.com/ tyurma-zarubezhom/tyuremnaya-sistema-velikobritanii

5. Пузирьов М. С. Виконання покарання у виді позбавлення волі на певний строк у зарубіжних країнах. Актуальні проблеми публічного та приватного права: монографія / Андрущенко Т. С., Аніщенко В. О., Зливко С. В. та ін.; за заг. ред. д-ра юрид. наук, проф. Ніщимної С. О. Чернігів: Академія Державної пенітенціарної служби, 2018. С. 366-428.

6. Андреященко Р. А. Пенитенциарная система Англии и Уэльса в XVI - XX вв. : историко-юридическое исследование. Автореферат диссертации на соискание ученой степени кандидата юридических наук : специальность 12.00.01 «Теория и история права и государства ; история учений о праве и государстве». Екатеринбург, 2006. $26 \mathrm{c}$. 
7. Муравйов К. Досвід США та Великобританії щодо реалізації державної політики у сфери виконання кримінальних покарань та можливості його використання в Україні, Підприємництво, господарство і право. 2017. № 1. С. 193-197.

8. Яценко С. С. Основні питання загальної частини кримінального права іноземних держав : навч. посібник; Київ. нац. ун-т ім. Тараса Шевченка. Київ : ВД «Дакор», 2013. 168 c.

\section{References}

Havronyuk, M. I. (2013). Naukove osmislennya pravovoyi doktrina ta kriminalnogo zakonodavstva zarubizhnih krayin. Visnik Asociaciï kriminalnogo prava Ukraïni, 1(1), 298347.

Yacishin, M. M., Krisyuk, Yu. P. (2018). Perspektivi reformuvannya penitenciarnoyi sistemi Ukrayini: dosvid Finlyandiyi. Visnik penitenciarnoyi asociaciyi Ukrayini, 3(5), 102110.

Puzirov, M. S. (2018). Vikonannya pokarannya u vidi pozbavlennya voli na pevnij strok u zarubizhnih krayinah. Aktualni problemi publichnogo ta privatnogo prava. Andrushenko T. S., Anishenko V. O., Zlivko S. V. ta in.; za zag. red. d-ra yurid. nauk, prof. Nishimnoyi S. O. Chernigiv: Akademiya Derzhavnoyi penitenciarnoyi sluzhbi, 366-428.

Andreyashenko, R. A. (2006). Penitenciarnaya sistema Anglii i Uelsa v XVI - XX vv.: istoriko-yuridicheskoe issledovanie. Avtoreferat dissertacii na soiskanie uchenoŭ stepeni kandidata yuridicheskih nauk. Ekaterinburg.

Muravı̌ov, K. (2017). Dosvid SShA ta Velikobritaniyi shodo realizaciyi derzhavnoyi politiki u sferi vikonannya kriminalnih pokaran ta mozhlivosti jogo vikoristannya $\mathrm{v}$ Ukrayini. Pidpriyemnictvo, gospodarstvo i pravo, 1, 193-197.

Yacenko, S. S. (2013). Osnovni pitannya zagalnoyi chastini kriminalnogo prava inozemnih derzhav. Kiyiv. nac. un-t im. Tarasa Shevchenka. Kiyiv : VD «Dakor».

\section{Shulika, graduate student of the Department of Theory and History of State and Law Lesya Ukrainka Volyn National University \\ ORCID: 0000-0003-3202-0463}

\section{The historiography of the penitentiarium of the UK in Ukrainian legal thought}

The article considers the historiography of British penitentiary law in the domestic legal thought, analyzes the work of Ukrainian researchers of the British penitentiary system. Scientific works in the field of criminal and criminal-executive law of Great Britain and their role in the improvement of the penitentiary system of Ukraine are analyzed. The main problematic aspects of the functioning of the penitentiary system are clarified and the prospects of further research of the penitentiary system of the United Kingdom are synthesized to outline possible ways to reform the penitentiary system of Ukraine.

The paper is based on the problems of the researched topic caused by the lack of a comprehensive study of British penitentiary in the Ukrainian legal doctrine.

The article serves as a confirmation that the Ukrainian doctrine of criminal law exists and develops taking into account the known achievements of foreign doctrine of criminal law, correct and erroneous decisions of criminal law policy and the 
provisions of criminal law of other states. The author reliably notes that novelties in the Ukrainian criminal legislation often appear under the influence of the provisions of the legislation of other states tested in practice or results of scientific researches of foreign scientists. As a result, criminal law in Ukraine is applied to some extent, as similar rules are applied in other countries.

The paper is written to outline the prospects for the implementation of the positive experience of the functioning of the British penitentiary system in the Ukrainian criminal executive legislation.

Keywords: penitentiary law; penitentiary law of Great Britain; penitentiary; penitentiary system; sources of penitentiary. 